\title{
HUBUNGAN WORK FAMILY CONFLICT DAN FAMILY WORK CONFLICT TERHADAP KETERLIBATAN KERJA PADA IBU BEKERJA DI RUMAH (WORK FROM HOME) DI MASA PANDEMI COVID-19
}

\author{
Devi Jatmika*1 \\ Program Studi Psikologi Universitas Bunda Mulia \\ Caroline Kezea Suryadi \\ Program Studi Psikologi Universitas Bunda Mulia
}

\begin{abstract}
The COVID-19 pandemic has changed people's normal activities, including work. During the pandemic, it enforced people to work from home to reduce the spread of the virus. Routines that are usually carried out in the office must be carried out at home. Therefore, it requires adaptation and causes role conflicts in working mothers. The demands of the role of mother at home together with the role of workers at home may have impacts on the work involvement of mothers. The aim of this study was to examine the relationship between work-family conflict and family-work conflict on the work involvement of mothers who work at home. The research method used non-experimental quantitative research methods. Participants in the study were mothers who worked in the Greater Jakarta area. The sample obtained was 132 respondents with an age range between 20-60 years. The sampling technique for data collection was convenience sampling technique. Data collection using a questionnaire. Work involvement variable is measured by The Utrecht Work Engagement Scale (UWES) and the scale of work-family conflict and family-work. Data analysis using Pearson correlation test technique. The results revealed that the hypothesis was not accepted, there was no significant relationship between work-family conflict and family-work conflict on work engagement. This research concluded working mom experienced work-family conflict and family-work conflict, however the demand of situation to work at home and the sense of responsibility cause work engagement not to be affected by conflict.
\end{abstract}

Keywords: work-family conflict, family-work conflict, work involvement, working mothers, work from home

Abstrak. Pandemi COVID-19 telah merubah aktivitas normal masyarakat termasuk dalam bekerja. Selama pandemi diberlakukan bekerja dari rumah atau work from home untuk mengurangi penyebaran virus. Rutinitas yang biasa di dikerjakan di kantor terpaksa dilakukan di rumah. Hal ini membutuhkan adaptasi dan menyebabkan konflik peran pada ibu yang bekerja. Tuntutan peran sebagai ibu di rumah bersamaan dengan peran pekerja di rumah diprediksi dapat berdampak terhadap keterlibatan kerja para ibu. Tujuan dari penelitian ini adalah untuk mengkaji hubungan antara work-family conflict dan family-work conflict terhadap keterlibatan ibu yang bekerja di rumah. Metode penelitian menggunakan metode penelitian kuantitatif non eksperimen. Partisipan dalam penelitian adalah ibu yang bekerja di daerah Jabodetabek. Sampel diperoleh sebanyak 132 responden dengan rentang usia 20-60 tahun. Teknik sampling untuk pengambilan data dengan teknik convenience sampling. Pengumpulan data menggunakan kuesioner. Variabel keterlibatan kerja diukur dengan The Utrecht Work Engagement Scale (UWES) dan skala work-family conflict dan family-work conflict (Schaufeli \& Bakker, 2003). Analisis data menggunakan teknik uji korelasi Pearson. Hasil penelitian menunjukkan hipotesis tidak diterima yaitu tidak ada hubungan signifikan work-family conflict dan family-work conflict terhadap keterlibatan kerja. Penelitian ini menyimpulkan ibu bekerja tetap mengalami work-family conflict dan family-work conflict, namun faktor tuntutan situasi untuk bekerja di rumah dan rasa tanggung jawab menyebabkan keterlibatan kerja tidak terpengaruh oleh konflik.

Kata kunci: work-family conflict, family-work conflict, keterlibatan kerja, ibu bekerja, bekerja di rumah

${ }^{1}$ Korespondensi: Devi Jatmika. Program Studi Psikologi Universitas Bunda Mulia, Jl. Lodan Raya No. 2, Jakarta Utara, 14430. Email: dephey@gmail.com 
Pandemi global akibat COVID-19 memaksa masyarakat untuk menjaga diri dengan jaga jarak (physical distancing) yang bertujuan untuk menekan laju infeksi virus. Kebijakan-kebijakan pemerintah untuk mengatasi COVID-19 menyebabkan perubahan di dunia kerja dalam waktu cepat. Hal ini termasuk kebijakan untuk bekerja dari rumah pada pegawai-pegawai perkantoran (Vibriyanti, 2020). Pola bekerja dari rumah ini membuat para orangtua harus terlibat dengan pekerjaan rumah tangga seperti mengurus anak, membimbing anak sekolah di rumah, menjaga keluarga besar, dan lainnya. Situasi yang baru ini menimbulkan psychological distress pada orangtua dan anak (Morelli et al., 2020). Beban pekerjaan rumah tangga dan tanggung jawab terhadap anak turut meningkat pada kedua orangtua baik ayah dan ibu yang bekerja di rumah. Akan tetapi, kesenjangan gender tidak dapat dihindarkan. Ibu yang bekerja di rumah melaporkan beban dua kali lipat lebih banyak daripada ayah yang bekerja di rumah (Dunatchik et al., 2021)

Data dari Kepala Dinas Tenaga Kerja, Transmigrasi dan Energi DKI Jakarta, Yansyah) di bulan April 2020 terdapat 3.711 perusahaan mematuhi aturan bekerja dari rumah. Lembaga Ilmu Pengetahuan Indonesia (LIPI) Bidang Ketenagakerjaan menyatakan sebanyak 78 persen pekerja yang bekerja dari rumah tetap bisa produktif. Perubahan dinamika cara kerja dari rumah meliputi melakukan pekerjaan kantor, rapat dan diskusi dengan rekan ataupun mitra kerja dilakukan secara daring. Adapula studi lainnya yang dilakukan oleh National Bureau of Economic Research kepada 3,1 juta pekerja, menyebutkan durasi jam kerja ketika bekerja di rumah menjadi lebih panjang. Rata-rata penambahan jam kerja menjadi bertambah 49 menit per hari, yang diikuti dengan lebih banyak rapat dan $e$ mail. Namun hasil ini tidak menjelaskan dari sisi jenis pekerjaan, penambahan jam kerja antara laki-laki dan perempuan serta kapasitas orang yang menangani pekerjaan (CNN Indonesia, 2020).

Bekerja dari rumah bersama anak yang masih kecil menjadi tantangan bagi ibu pekerja saat bekerja dari rumah. Para ibu dihadapkan pada pilihan untuk fokus bekerja, mengurus anak dan mengurus rumah. Komisi Perlindungan Anak Indonesia (KPAI) melakukan survey secara daring sejak 8-14 Juni 2020 kepada 25.146 anak di Indonesia, menyatakan selama pandemi kerap mendapat kekerasan fisik maupun psikis dari kedua orang tuanya. Bentuk kekerasan fisik yang dialami seperti dicubit $(39,8 \%)$, dijewer $(19,5 \%)$, dipukul $(10,6 \%)$, dan ditarik $(7,7 \%)$. Bentuk kekerasan psikis antara lain dimarahi (56\%), dibandingkan dengan anak yang lain $(34 \%)$, dibentak $(23 \%)$, dan dipelototi (13\%). Baik kekerasan fisik maupun psikis ini ditemukan lebih banyak dilakukan oleh ibu. Kekerasan fisik yang dilakukan ibu sebesar 60,4\% dan kekerasan psikis sebanyak 79\%. (Dewi, 2020). Perilaku ibu yang demikian tidak terlepas dari beban ibu pekerja selama pandemi.

Komnas Perempuan (2020) melakukan survei di pulau Jawa dengan hasil bahwa perempuan mengerjakan pekerjaan rumah tangga dua kali lipat daripada laki-laki. Durasi yang dihabiskan dalam sehari mencapai lebih dari 3 jam. Sebanyak 1 dari 3 responden melaporkan bahwa pekerjaan rumah tangga membuat mereka semakin stres. Hal ini dikarenakan peran ibu yang secara bersamaan harus mendampingi anak selama belajar dari rumah dan menjadi guru di rumah. Selain itu dampak lainnya adalah adanya kesenjangan jam kerja. Collins, Landivar, Ruppanner, dan Scarborough (2021) menemukan ibu dengan anak balita harus mengurangi jam kerja mereka empat hingga lima kali daripada ayah karena harus mengurus pekerjaan domestik dan mengurus anak.

Waumsley, Houston, dan Marks (2010) dalam penelitiannya menyebutkan 
hubungan antara identitas organisasional berhubungan dengan work-family conflict pada wanita yang dengan atau tidak memiliki anak, seseorang mengalami konflik yang lebih sedikit antara pekerjaan dan keluarga jika mereka semakin mengidentifikasi dirinya dengan organisasi. Wanita yang memiliki anak merasakan konflik keluarga terhadap pekerjaan yang lebih besar daripada konflik antara pekerjaan terhadap keluarga dan kehidupan mereka. Konflik keluarga terhadap pekerjaan juga berhubungan positif yang kuat terhadap psychological distress. Ketika karyawan tidak dapat menyeimbangkan peran di pekerjaan dan keluarga dan terjebak dalam konflik dalam waktu yang lama, mereka akan merasa kelelahan fisik dan mental atau dikenal dengan burnout (Robinson, et.al, 2016). Work-family conflict dan family-work conflict berdampak pada kesehatan fisik dan mental karyawan meliputi perasaan stres (Waumsley, Houston \& Marks, 2010), kepuasan kerja (Rahman, Ali, Jantan, Dato'Mansor \& Rahaman, 2020) absen dari tempat kerja (Nilsen et al, 2017) dan keluar dari pekerjaan (Jain \& Nair, 2013).

Dalam penelitian-penelitian terdahulu, work-family conflict diukur secara satu arah. Namun, seiring perkembangan penelitian hubungan antara pekerjaan dan keluarga bersifat dua arah, yang artinya pekerjaan dapat mencampuri peran terhadap keluarga dan keluarga dapat mengganggu pekerjaan (Cinamon \& Rich, 2012). Work-family conflict merupakan ketidakseimbangan antara peran dan tanggungjawab yang menjadi sumber stres ketika individu memberikan waktu yang lebih banyak untuk bekerja sehingga waktu untuk keluarga berkurang dan menjadi konflik. Sebaliknya family-work conflict adalah konflik yang terjadi ketika individu tidak mampu memenuhi peran dalam pekerjaan karena harus memenuhi peran dalam keluarga. Ada tiga aspek pada masing-masing work-family conflict dan family-work conflict yaitu time-based, strain-based dan behavior-based conflicts (Carlson, Kacmar \& Williams, 2000). Time-based conflict terjadi jika waktu yang digunakan untuk memenuhi satu peran tidak cukup digunakan untuk memenuhi peran lainnya. Strain-based conflict ditandai dengan munculnya ketegangan emosional dalam memenuhi satu peran sehingga ketegangan ini menghambat pemenuhan peranan lainnya. Behaviorbased conflict terjadi saat perilaku di satu peran tidak sesuai dengan perilaku di peranan lainnya.

Schaufeli (2013) menjelaskan bahwa ketika organisasi dihadapkan pada perubahan, maka dibutuhkan adaptasi psikologis dan keterlibatan dari seluruh karyawan. Sehingga, diperlukan kapabilitas psikologis pada karyawan agar organisasi dapat berjuang dan bertahan yaitu keterlibatan kerja karyawan atau work engagement. Karyawan yang terlibat secara konsisten akan berbicara positif dalam mengenai organisasinya kepada rekan kerja lain ataupun konsumen, keinginan kuat untuk bertahan di organisasi dan memberikan usaha, waktu dan inisiatif yang lebih untuk kesuksesan organisasi (Schaufeli, 2013). Oleh karena itu, di masa pandemi ini, organisasi sangat membutuhkan engagement dari para karyawan agar dapat bertahan menghadapi perubahanperubahan organisasi.

Keterlibatan kerja adalah antitesis dari burnout, karyawan yang terlibat dalam pekerjaannya memiliki rasa energetik, efektif dalam pekerjaannya, yang berlawanan dengan burnout yang dicirikan dengan kelelahan fisik dan mental. Schaufeli (2013) mendefinisikan keterlibatan kerja sebagai keadaan pikiran yang positif, memuaskan yang dikarakteristikkan dengan vigor, dedication dan absorption. Aspek pertama, vigor merupakan komponen perilaku. Karyawan yang memiliki vigor akan mencurahkan 
energi dan mental yang kuat, berusaha sekuat tenaga untuk menyelesaikan pekerjaan dan tekun dalam menghadapi kesulitan kerja. Kedua, dedication merujuk pada komponen emosional. Karakteristik karyawan dengan dedication mau untuk terlibat dalam pekerjaannya, mendapatkan rasa kebanggaan, makna, antusias, inspirasi dan tantangan dari pekerjaannya. Ketiga, aspek absorption berkaitan dengan komponen kognitif. Karyawan mampu sepenuhnya konsentrasi, serius dan menikmati saat melakukan pekerjaannya. Lebih lanjut, keterlibatan kerja ini berbeda dengan kecanduan bekerja atau workacholic. Seseorang yang kecanduan bekerja dimotivasi oleh dorongan kompulsif yang tidak dapat ditahan untuk terus bekerja.

Penelitian sebelumnya, Lyu \& Fan (2020) memperoleh hasil penelitian tidak adanya perbedaan antara work-family conflict dan family-work conflict pada pria dan wanita. Baik pria maupun wanita tidak akan menurunkan keterlibatan pekerjaannya jika dihadapkan pada isu work-family conflict. Namun, pada wanita akan menurun keterlibatan kerjanya ketika dihadapkan pada isu family-work conflict. Penelitian sebelumnya, Kesumaningsari dan Simarmata (2014) pada karyawati bank di Bali diperoleh adanya hubungan negatif yang signifikan antara work-family conflict terhadap work engagement. Begitupula, penelitian Opie dan Henn (2013) menemukan work-family conflict adalah prediktor dari keterlibatan kerja, semakin tinggi konflik maka semakin rendah pula keterlibatan kerja. Stres yang diakibatkan oleh work-family conflict mencegah ibu bekerja untuk konsentrasi secara optimal dan mendedikasikan waktu dan energinya terhadap peran di pekerjaan.

Dalam penelitian sebelumnya di Indonesia, lebih banyak mengukur konflik kerjakeluarga namun dalam penelitian ini peneliti akan mengembangkan penelitian konflik kerja-keluarga (work-family conflict) dengan mengukur pula konflik keluarga-kerja (family-work conflict) karena adanya tekanan dalam menyeimbangkan kedua peran tersebut pada ibu yang bekerja di masa pandemi COVID-19 serta hubungannya keterlibatan kerjanya saat bekerja di rumah. Maka dari itu, penelitian ini bertujuan untuk menemukan hubungan antara work-family conflict, family-work conflict terhadap keterlibatan kerja pada ibu yang bekerja di masa pandemi COVID-19. Hipotesis dalam penelitian ini terdiri dari:

H1: Ada hubungan negatif work-family conflict terhadap keterlibatan kerja pada ibu yang bekerja di rumah di masa pandemi COVID-19.

H2: Ada hubungan negatif family-work conflict terhadap keterlibatan kerja pada ibu yang bekerja di rumah di masa pandemi COVID-19.

\section{METODE}

Partisipan dalam penelitian ini adalah wanita yang memiliki anak, masih ataupun pernah bekerja di rumah selama COVID19. Partisipan berdomisili di area Jabodetabek dan merupakan karyawan tetap. Teknik sampling yang dilakukan adalah convenience sampling. Jumlah responden sebanyak 132 responden.

Alat ukur yang digunakan untuk mengukur work-family conflict dan family-work conflict adalah skala work-family conflict dan family-work conflict yang dikembangkan oleh Carlson, Kacmar \& Williams (2000). Alat ukur ini terdiri dari 6 dimensi yang terdiri dari time-based work interference with family, time-based family interference with work, strain-based work interference with family, strain-based family interference with work, behaviorbased work interference with family, behavior-based family interference with work dengan jumlah butir sebanyak 18 butir. Skala memiliki rentang skala Likert, 
skor 1 (sangat tidak setuju) hingga skor 5 (sangat setuju).

Variabel keterikatan kerja diukur dengan The Utrecht Work Engagement Scale (UWES) oleh Schaufeli and Bakker (2003). Skala UWES terdiri dari 17 aitem dengan tiga dimensi yaitu 6 aitem untuk dimensi vigor, 5 aitem untuk dimensi dedication dan 6 aitem untuk absorption. Skala UWES memiliki reliabilitas yang tinggi dan telah digunakan di berbagai penelitian keterlibatan kerja. Skala UWES menggunakan 7 poin skala Likert dimulai dari poin 0-6 (tidak pernah hingga setiap hari).

Alat ukur melalui uji coba terlebih dahulu kepada 30 orang responden untuk mengetahi reliabilitas dan validitas penelitian. Hasil uji reliabilitas dengan alpha cronbach diperoleh dimensi timebased work interference with family, memiliki nilai relibilitas $\alpha=0.865$, strainbased work interference with family, $\alpha=$ 0.886, dimensi behavior-based work interference with family dengan nilai reliabilitas $\alpha=0.576$, dimensi time-based family interference with work dengan nilai reliabilitas $\alpha=0.645$, strain-based family interference with work, nilai reliabilitas $\alpha=$ 0.7 , behavior-based family interference with work dengan nilai reliabilitas $\alpha=0.824$. Secara keseluruhan, dapat dikatakan alat ukur konflik peran ganda adalah reliabel. Alat ukur keterlibatan kerja, pada ketiga aspek vigor, dedication dan absorption memiliki nilai reliabitas 0.9 , sehingga alat ukur ini tergolong sangat reliabel.

Uji asumsi yang dilakukan dalam penelitian ini adalah dengan melakukan uji normalitas menggunakan Kolmogorov Smirnov. Hasil uji normalitas diperoleh variabel workfamily conflict, family-work conflict dan keterlibatan kerja memiliki nilai sig $>0.05$ sehingga dapat disimpulkan data berdistribusi normal. Teknik analisa data menggunakan teknik korelasi Pearson, hasil dinyatakan ada hubungan yang signifikan jika korelasi antar variabel memiliki nilai $\mathrm{p}$ $<0.05$.

\section{HASIL DAN DISKUSI}

Data responden dalam penelitian yang berhasil diperoleh berjumlah 138 responden, namun data yang dapat diolah sebanyak 132 data responden. Gambaran umum responden ditinjau dari usia, pendidikan akhir, jumlah anak, status menikah, domisili tempat tinggal, jenis pekerjaan dapat dilihat pada tabel berikut:

Tabel 1.

Gambaran Demografi Responden

\begin{tabular}{|c|c|c|c|}
\hline $\begin{array}{l}\text { Karakteristik } \\
\text { Responden }\end{array}$ & Kategori & $\begin{array}{c}\text { Freku } \\
\text { ensi }\end{array}$ & $\begin{array}{l}\text { Persen- } \\
\text { tase }(\%)\end{array}$ \\
\hline \multirow{2}{*}{ Usia } & 20-39 tahun & 98 & 74.2 \\
\hline & $40-60$ tahun & 34 & 25.8 \\
\hline \multirow{5}{*}{$\begin{array}{l}\text { Pendidikan } \\
\text { terakhir }\end{array}$} & SMA/ SMK & 8 & 6 \\
\hline & Diploma & 23 & 17.4 \\
\hline & S1 & 69 & 52.3 \\
\hline & S2 & 28 & 21.2 \\
\hline & S3 & 4 & 3 \\
\hline \multirow{4}{*}{ Jumlah anak } & 1 & 54 & 40.9 \\
\hline & 2 & 57 & 43.2 \\
\hline & 3 & 16 & 12.1 \\
\hline & 4 & 5 & 3.8 \\
\hline \multirow{2}{*}{$\begin{array}{c}\text { Status } \\
\text { menikah }\end{array}$} & Menikah & 119 & 90.2 \\
\hline & $\begin{array}{l}\text { Single } \\
\text { Parent }\end{array}$ & 13 & 9.8 \\
\hline \multirow{5}{*}{$\begin{array}{l}\text { Domisili } \\
\text { tempat tinggal }\end{array}$} & Jakarta & 59 & 44.8 \\
\hline & Bogor & 21 & 15.9 \\
\hline & Depok & 14 & 10.6 \\
\hline & Tangerang & 16 & 12.1 \\
\hline & Bekasi & 22 & 16.7 \\
\hline \multirow{3}{*}{$\begin{array}{c}\text { Jenis } \\
\text { pekerjaan }\end{array}$} & $\begin{array}{c}\text { Profesi } \\
\text { (guru, dosen, } \\
\text { dll) }\end{array}$ & 27 & 20.5 \\
\hline & $\begin{array}{l}\text { Pegawai } \\
\text { swasta/ } \\
\text { BUMN }\end{array}$ & 102 & 76.5 \\
\hline & ASN/ PNS & 4 & 3 \\
\hline
\end{tabular}


Subjek penelitian terdiri dari ibu bekerja dengan rentang kelompok usia 20-39 tahun sebanyak 98 orang $(7.2 \%)$ dan kelompok usia 40-60 tahun (34\%). Pendidikan terkahir responden sebagain besar adalah sarjana S1 sebesar 52.3\%, jumlah anak terbanyak adalah ibu memiliki 2 anak dan 1 anak. Ibu bekerja yang menikah sebanyak 119 orang dan yang menjadi single parent sebanyak 13 orang. Domisili tempat tinggal responden terbanyak adalah di Jakarta. Jenis pekerjaan dari responden sebagian besar adalah pegawai atau karyawan swasta/BUMN dengan jumlah 102 orang. Gambaran deskriptif dari variabel penelitian diketahui variabel work-family conflict memiliki nilai rata-rata, $\mathrm{M}=27.03$; $\mathrm{SD}=9.03$, variabel family-work conflict memiliki nilai $\mathrm{M}=26.8 ; \mathrm{SD}=9$, dan variabel keterlibatan kerja memiliki nilai $\mathrm{M}=66.5 ; \mathrm{SD}=24.19$.

Kategorisasi variabel menggunakan norma mean hipotetik. Pada variabel keterlibatan kerja, jika mean responden > 3 maka dikategorikan tinggi. Begitupula, variabel work-family conflict dan family-work conflict dikategorikan tinggi jika mean hipotetik responden $>3$. Dari hasil tabel 1 . diperoleh work engagement ibu bekerja ketika WFH tergolong tinggi, work-family conflict dan family-work conflict tergolong rendah.

Tabel 2.

Kategorisasi Variabel

\begin{tabular}{lcc}
\hline Variabel & Tinggi (\%) & Rendah (\%) \\
\hline $\begin{array}{c}\text { Keterlibatan } \\
\text { kerja }\end{array}$ & $90(68.2 \%)$ & $42(31.8 \%)$ \\
$\begin{array}{c}\text { Work-family } \\
\text { conflict }\end{array}$ & $60(45.5 \%)$ & $72(54.5 \%)$ \\
$\begin{array}{c}\text { Family-work } \\
\text { conflict }\end{array}$ & $58(43.9 \%)$ & $74(56.1 \%)$ \\
\hline
\end{tabular}

Uji korelasi dengan menggunakan teknik Pearson Correlation diperoleh variabel work-family conflict tidak berhubungan signifikan terhadap keterlibatan kerja. Begitupula dengan family-work conflict dengan keterlibatan kerja, karena nilai signifikansi > 0.05 Tabel hasil korelasi sebagai berikut:

Tabel 3.

Hasil Uji Korelasi

\begin{tabular}{ccc}
\hline Keterlibatan Kerja & $r$ & $\mathrm{p}$ \\
\hline Work-family conflict & -0.61 & 0.484 \\
Family-work conflict & -0.13 & 0.880 \\
\hline
\end{tabular}

Hasil uji korelasi diperoleh tidak adanya hubungan signifikan antara work-family conflict terhadap keterlibatan kerja, dan tidak ada hubungan yang signifikan antara family-work conflict terhadap keterlibatan kerja. Hal ini menunjukkan bahwa hipotesis tidak diterima.

Pertama, terkait tidak ada hubungan signifikan antara family-work conflict terhadap keterlibatan kerja ibu yang bekerja. Hasil penelitian ini berbeda dengan penelitian sebelumnya Lyu \& Fan (2020) bahwa terdapat hubungan signifikan pada family-work conflict terhadap work engagement ada perempuan yang mencari nafkah. Pada penelitian sebelumnya di China dijelaskan bahwa norma dan moralitas sosial mempengaruhi peran wanita dalam keluarga yang mana ketika peran dalam keluarga mengganggu pekerjaan, maka waktu dan sumber daya yang diberikan untuk pekerjaan akan menurun dan memprediksi keinginan untuk berhenti bekerja (Huang \& Cheng dalam Lyu \& Fan, 2020). Ibu bekerja ditemukan memiliki nilai-nilai kerja (work values) yang tinggi, walaupun terdapat perempuanperempuan yang membayar asisten rumah tangga, mereka tetap mencurahkan perhatiannya untuk anak dan pekerjaan rumah tangga. Selain itu, ibu bekerja dilaporkan memberikan tingkat kepentingan yang lebih tinggi pada familywork conflict (Cinamon \& Rich, 2002). Dari hasil penelitian Cinamon dan Rich (2002), menjelaskan hasil penelitian ini yaitu nilai-nilai kerja yang tinggi dan rasa kewajiban yang tinggi terhadap pekerjaan 
kantor tidak mempengaruhi keterlibatn kerja mereka selama di rumah.

Kedua, tidak adanya hubungan signifikan antara work-family conflict terhadap keterlibatan kerja dijelaskan sebagaimana dalam penelitian Lyu \& Fan (2020) bahwa tidak ada hubungan work-family conflict terhadap keterlibatan kerja. Penelitian ini dilakukan pada ibu bekerja saat COVID-19, yang mana adanya pengurangan jam kerja selama pandemi sehingga memungkinkan wanita untuk menjalankan perannya sebagai ibu ketika di rumah walaupun di tengah work from home (Schieman, Badawy, Milkie \& Bierman, 2020). McKeever dalam Spurk \& Straub (2020) menyebutkan orang-orang yang bekerja di rumah beradaptasi dengan jam kerja, termasuk interupsi dan gangguan karena kewajiban keluarga. Adanya fleksibilitas ini turut meningkatkan jam kerja harian. Faktor fleksibilitas jam kerja dan kapan pekerjaan yang berubah ketika bekerja di rumah ini membuat ibu bekerja dapat mengelola kapan pekerjaannya ingin dilakukan sehingga work-family conflict tidak mempengaruhi keterlibatan kerja.

\section{KESIMPULAN}

Dari penelitian disimpulkan adanya tidak adanya hubungan antara work-family conflict terhadap keterlibatan kerja dan tidak ada hubungan signifikan antara family-work conflict terhadap keterlibatan kerja. Faktor-faktor seperti dukungan sosial dari keluarga, fleksibilitas jam kerja dan nilai-nilai kerja yang dimiliki individu ketika bekerja di rumah saat pandemi COVID-19 memungkinkan pada ibu untuk mengelola kedua peran sehingga workfamily conflict dan family-work conflict tidak berhubungan terhadap keterlibatan kerja.

Keterbatasan dalam penelitian ini adalah jumlah sampel yang terbatas karena sulitnya mendapatkan responden yang bersedia mengisi kuesioner daring dan karakteristik pekerjaan dari responden yang masih luas. Penelitian selanjutnya diharapkan dapat memperbanyak sampel penelitian. Dalam penelitian ini variasi jenis pekerjaan para ibu juga terbatas yang mana mayoritas adalah ibu kantoran sehingga tidak dapat dibandingkan. Saran untuk penelitian selanjutnya adalah dapat melihat family-work conflict dan workfamily conflict dari berbagai jenis pekerjaan sehingga diketahui jenis pekerjaan mana yang paling terdampak saat bekerja di rumah. Tambahan lain untuk penelitian berikutnya adalah mengkaji dukungan organisasi, dukungan suami dan persepsi tentang beban kerja selama pandemi pada ibu yang bekerja di rumah.

Saran praktis bagi ibu di rumah adalah tetap mencari sumber-sumber pendukung untuk mengatasi family-work conflict dan workfamily conflict ketika harus bekerja di rumah seperti kerjasama dengan pasangan untuk melakukan kewajiban rumah tangga, membuat jadwal-jadwal kapan untuk mengerjakan tugas kantor dan tugas di rumah serta memiliki waktu pribadi untuk beristirahat dan rileks. Selain itu, untuk mempertahankan dan tetap meningkatkan keterlibatan kerja di rumah, para ibu diharapkan mampu memaknai pekerjaan yang dilakukannya saat ini dan berupaya untuk memberikan kontribusi dan hasil untuk pekerjaannya di tengah pandemi COVID-19.

\section{Ucapan Terima Kasih}

Ucapan terima kasih penulis tunjukkan kepada Universitas Bunda Mulia yang telah mendukung penelitian dosen melalui hibah penelitian. Penulis juga ucapkan terima kasih kepada dukungan program studi Psikologi Universitas Bunda Mulia dan pihak-pihak yang telah membantu terlaksananya penelitian ini. 


\section{DAFTAR PUSTAKA}

Carlson, D. S., Kacmar, K. M., \& Williams, L. J. (2000). Construction and initial validation of a multidimensional measure of work-family conflict. Journal of Vocational Behavior, 56(2), 249-276. doi:10.1006/jvbe.1999.1713

Cinamon, R. G., \& Rich, Y. (2002). Gender differences in the importance of work and family roles: implications for workfamily conflict. Sex Roles, 47(11/12), 531-541. doi:10.1023/a:1022021804846

Collins, C., Landivar, L. C., Ruppanner, L., \& Scarborough, W. J. (2021). COVID19 and the gender gap in work hours. Gender Work Organ, 28(1), 1-12. doi:10.1111/gwao.12506

Dunatchik, A., Gerson, K., Glass, J., Jacobs, J. A., \& Stritzel, H. (2021). Gender, parenting, and the rise of remote work during the pandemic: Implications for domestic inequality in the United States. Gender \& Society, 35(2), 194205. doi:10.1177/08912432211001301

Dewi, N. (2020, 1 Agustus). Sulitnya menjadi ibu pekerja selama pandemi. Tirto.id. Diunduh dari https://tirto.id/sulitnya-menjadi-ibupekerja-selama-pandemi-fTYi

Idham, A. M. (2020, 10 September). Jadwal PSBB Jakarta terbaru, aturan WFH dan 11 bidang pengecualian. Tirto.id. Diunduh dari https://tirto.id/jadwalpsbb-jakarta-terbaru-aturan-wfh-dan11-bidang-pengecualian-f36A

Jain, S., \& Nair, S. K. (2013). Research on work-family balance: A review. Business Perspectives and Research, 2(1), 43-58. doi:10.1177/2278533720130104

Kesumaningsari, N. P. A., \& Simarmata, N. (2014). Konflik kerja-keluarga dengan kepuasan kerja yang dimoderasi komitmen organisasi pada karyawan Bali. Jurnal Psikologi Udayana, 105118. Diunduh dari https://ojs.unud.ac.id/index.php/psikolo gi/article/view/25131

Lyu, X., \& Fan, Y. (2020). Research on the relationship of work family conflict, work engagement and job crafting: A gender perspective. Current Psychology. doi: 10.1007/s 12144-020-00705-4

Morelli, M., Cattelino, E., Baiocco, R., Trumello, C., Babore, A., Candelori, C., \& Chirumbolo, A. (2020). Parents and children during the covid-19 lockdown: The influence of parenting distress and parenting self-efficacy on children's emotional well-being. Frontiers in psychology, $\quad 11, \quad 584645$. doi:10.3389/fpsyg.2020.584645

Nilsen, W., Skipstein, A., Østby, K. A., Mykletun, A. (2017). Examination of the double burden hypothesis - a systematic review of work-family conflict and sickness absence. European Journal of Public Health, 27(3), 465-471. doi:10.1093/eurpub/ckx054

Opie, T., \& Henn, C. (2013). Work-family conflict and work engagement among mothers: Conscientiousness and neuroticism as moderators. SA Journal of Industrial Psychology, 39(1), 1-12. doi:10.4102/sajip.v39il.1082

Rahman, M. M., Ali, N. A., Jantan, A. H., Dato'Mansor, Z., \& Rahaman, M. S. (2020). Work to family, family to work conflicts and work family balance as predictors of job satisfaction of Malaysian academic community. Journal of Enterprising Communities: People and Places in the Global Economy, 14(4), 621-642. doi:10.1108/JEC-05-2020-0098 
Robinson, L. D., Magee, C., \& Caputi, P. (2016). Burnout and the work-family interface: A two-wave study of sole and partnered working mothers. Career Development International, 21(1), 3144. doi:10.1108/CDI-06-2015-0085

Schaufeli, W. B., \& Bakker, A. B. (2003). Test manual for the Utrecht Work Engagement Scale. Unpublished manuscript, Department of Psychology, Utrecht University, Utrecht, Netherlands.

Schaufeli, W. B. (2013). What is engagement? Dalam C. Truss, K. Alfes, R. Delbridge, A. Shantz, \& E. Soane (Eds.), Employee Engagement in Theory and Practice. (hal.15-35). London: Routledge.

Schieman, S., Badawy, P. J., Milkie, M. A., \& Bierman, A. (2021). Work-life conflict during the COVID-19 pandemic. Socius: Sociological Research for a Dynamic World, 7, 1-19. doi:10.1177/2378023120982

Spurk, D., \& Straub, C. (2020). Flexible employment relationships and careers in times of the COVID-19 pandemic. Journal of Vocational Behavior, 119, 103435. doi:10.1016/j.jvb.2020.103435

Tim CNN Indonesia. (2020, 9 September). Studi soal WFH: Kerja lebih panjang dan rapat lebih banyak. CNN Indonesia. Diunduh dari https://www.cnnindonesia.com/gaya- hidup/20200901102717-284-

541464/studi-soal-wfh-kerja-lebihpanjang-dan-rapat-lebih-banyak

Vibriyanti, D. (2020, 5 Mei). Work from home: Cara bekerja baru di masa pandemi COVID-19. LIPI Pusat Penelitian Kependudukan. Diunduh dari https://kependudukan.lipi.go.id/id/berita 153-mencatatcovid19/856-work-fromhome-cara-bekerja-baru-di-masapandemi-covid-19

Waumsley, J. A., Houston, D. M., \& Marks, G. (2010). What about us? Measuring the work-life balance of people who do not have children. Review of European Studies, 2(2), 3-17. doi:10.5539/res.v2n2p3 